people, it was off the line of the Solomon Islands campaign. The Tikopians, he says, "were spared the traumatic experience of most other islands ; neither the Japanese nor the Americans established a base there".

But he also found that a few of the islanders had, after the War, gone to work in the Solomon Islands proper ; that the people's geographical notions, previously more or less confined to Anuta and perhaps Vanikoro, had consequently received a modest expansion, that Christianity as taught by the Anglican Melanesian Mission had increased its majority over paganism, that money was beginning to co-exist with barter.

When Prof. Firth first resided in Tikopia, the men of the island presented a striking appearance of a bizarre and unique kind; tall, slim and well-built, they grew their hair as long as possible and bleached it with applications of lime to a golden shade, so that at a distance they seemed to be maned like lions. This was still the case when I myself visited the island more than a decade later, just before war came to the Pacific. On his return, Firth found that most of the younger men were wearing their hair short, and that some of the canoes that came out to meet him were paddled by exclusively female crews, "a striking cultural novelty".

Tikopia is too distant from any Government centre and too small for direct administration, even if this were thought to be suitable. Thus, the traditional local forms of autonomy have had the chance to survive; and Prof. Firth thinks that, even with increasing contact with the Government, the power of the chiefs is likely to grow so long as the Government accepts their authority. "With the clearer emergence of the Tikopian Chief as a secular power, recognition of him as such by the Government is likely to consolidate his general status".

Some artists-Tintoretto, for example--work on a vast canvas; others choose the technique of the miniature. Prof. Firth, in his two major books on the Tikopians, belongs to the latter class. He has devoted an appreciable period of his life to the study of a tiny community-1,200 souls during his first stay, 1,700 on his return-and he has dealt with it in the utmost detail. He has done well to do so, for Tikopia is not only, as he points out, "a highly structural society" but it is also a homogeneous one, saved by its geographical isolation from the drastic and sometimes disastrous changes that the Second World War has wrought in other primitive com. munities. He has, by this full account of his return to the scene of his former studies, conferred a benefit on all students of the Pacific. H. C. Luke

\section{FACT AND OPINION}

The Anatomy of Judgment

An Investigation into the Processes of Perception and Reasoning. By Dr. M. L. Johnson Abercrombie. Pp. $156+7$ plates. (London: Hutchinson and Co. (Publishers), Ltd., 1960.) 25s. net.

THE author of this short book is a zoologist who has been much concerned with the selection and training of medical students. As a university teacher, she had become increasingly sceptical about tho effects of an ordinary scientific education upon the capacity to think, and was therefore led to embark upon a most courageous experiment in education. This, essentially, was a free discussion class in which a dozen or so students were tactfully prevailed upon to scrutinize their own processes of observation and inference. For example, a discussion built around the incidence of 'observer error' in the interpretation of radiographs served to bring out the role of hidden inferences in the reporting of 'facts'. Other discussions were concerned with the meanings of words (for example, the word 'normal' as used in biology or medicine), with the rationale of classification and the evaluation of evidence. These classes were certainly not meant to provide formal instruction in logic or scientific method. Rather was it hoped that the participants, by gaining insight into their own preconceptions, would gradually attain a more original and genuinely objective approach to scientific issues. Although it is difficult to be sure, there is reason to believe that the new method achieved a very fair measure of success.

Although mainly concerned with cognitive issues, Dr. Johnson Abercrombie clearly finds it essential to devote some consideration to factors of temperament. Indeed she has gone out of her way to learn something of the techniques of modern psychotherapy and traces a most interesting parallel between her discussion classes and group psychotherapy. In both settings, discussion of topics apparently impersonal may serve to uncover insecurities at a deeper level. It follows, therefore, that educational experiments of the kind Dr. Johnson Abercrombie describes are not to be undertaken lightly. None the less, if we are to make the best of scientific education, it seems essential that we should discover ways to liberate the student from the security of his accepted patterns of opinion and thought. Dr. Johnson Abercrombie's work is at least a first step in this direction and, after all, c'est le premier pas qui coute.

Dr. Johnson Abercrombie's experience has stimulated her to inquire seriously into the psychology of perception and judgment and to attempt to place her findings within a broader psychological context. Indeed, the first part of her book provides a useful review of modern work in this field, with particular reference to the parts played by attitudes and experience in governing perceptual activity. Although her account is quite well done, it cannot perhaps be said to add anything to the numerous accounts of the subject already available. The value of this book lies above all in the description given of a fascinating real-life experiment and in its very real implications for the theory and practice of education.

O. L. ZANGWILL

\section{FRANCIS BACON WITHOUT HIS BACKGROUND}

\section{Francis Bacon}

The First Statesman of Science. By J. G. Crowther. Pp. $x v+362+7$ plates. (London: The Cresset Press. 1960.) 35s. net.

rHIS big book falls into two parts. The first, "For Mankind", is an attempt to estimate Bacon's scientific achievement. The second part, "For Himself", offers a biography of the statesman. The suggestion here, that Bacon was in politics for private ends, is unfortunate, and does not really represent Crowther's view. For he has written a full and sympathetic study of Bacon's public career, which can be read with pleasure and is, in my judgment, the more successful portion of the book. 